STUDI

FRANCESI

\section{Studi Francesi}

Rivista quadrimestrale fondata da Franco Simone

171 (LVII | III) | 2013

FRANCO SIMONE E LA STORIOGRAFIA LETTERARIA -

Atti della giornata di studi nel centenario della nascita promossa dall'Accademia delle Scienze di Torino in collaborazione con «Studi Francesi» Torino - 24 maggio 2013

\title{
Anne Dubois, Quelques remarques sur des monogrammes de la seconde moitié du $X V^{\mathrm{e}}$ siècle
}

\author{
Maria Colombo Timelli
}

\section{(2) OpenEdition}

\section{Édition électronique}

URL : http://journals.openedition.org/studifrancesi/2697

DOI : 10.4000/studifrancesi.2697

ISSN : 2421-5856

Éditeur

Rosenberg \& Sellier

\section{Édition imprimée}

Date de publication : 1 décembre 2013

Pagination : 582

ISSN : 0039-2944

\section{Référence électronique}

Maria Colombo Timelli, « Anne Dubois, Quelques remarques sur des monogrammes de la seconde moitié du xve siècle», Studi Francesi [En ligne], 171 (LVII | III) | 2013, mis en ligne le 30 novembre 2015, consulté le 18 septembre 2020. URL : http://journals.openedition.org/studifrancesi/2697; DOI : https://doi.org/10.4000/studifrancesi.2697

Ce document a été généré automatiquement le 18 septembre 2020.

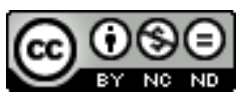

Studi Francesi è distribuita con Licenza Creative Commons Attribuzione - Non commerciale - Non opere derivate 4.0 Internazionale. 


\title{
Anne Dubois, Quelques remarques sur des monogrammes de la seconde moitié du $X V^{\mathrm{e}}$ siècle
}

\author{
Maria Colombo Timelli
}

\section{RÉFÉRENCE}

ANNE DUBOIS, Quelques remarques sur des monogrammes de la seconde moitié $d u x^{e}$ siècle, «Scriptorium», 66, 2012, pp. 156-165, pl. 27-30.

1 Dans le cadre de ses recherches sur les manuscrits de la traduction française des Facta et dicta memorabilia de Valère Maxime par Simon de Hesdin et Nicolas de Gonesse, A.D. étudie particulièrement ici le monogramme composé de lettres cursives gothiques stylisées qui est peint à la main dans les marges de l'editio princeps de ce texte (exemplaire conservé à Paris, BnF, Rés. Z.200-201). La comparaison de cet emblème avec d'autres monogrammes de même style (dans des mss ayant appartenu au couple Charlotte de Bourbon-Montpensier et Wolfart VI de Borssele, à Adolphe de Clèves, au couple Antoine Rolin et Marie d'Ailly, à Isabelle de Lalaing, à Philippe de Croÿ) lui permet d'émettre l'hypothèse que la longue hampe centrale peut correspondre à un lacs d'amour stylisé. 